\title{
Study the effect of different temperatures on the biofilm production in Proteus mirabilis isolated from urinary tract infection patients.
}

\author{
Ali A. Ghazay ${ }^{\mathrm{a}}$ Abbas Mayar Hezam ${ }^{\mathrm{b}}$ Mohammed M. Alkhuzaie ${ }^{\mathrm{c}}$ Israa Salih \\ Obayes $^{d}$

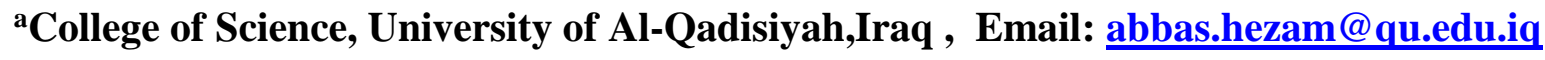

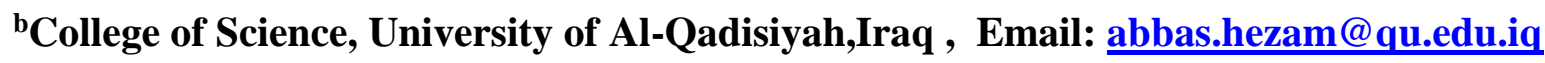 \\ cCollege of Science, University of Al-Qadisiyah,Iraq, Email: alkhuzaie40@ gmail.com \\ ${ }^{\text {d} C o l l e g e ~ o f ~ S c i e n c e, ~ U n i v e r s i t y ~ o f ~ A l-Q a d i s i y a h, I r a q, ~ E m a i l: ~ i s r a a s a l i h 8 @ ~ g m a i l . c o m ~}$
}

\begin{abstract}
15 isolates (39.4\%) of Proteus mirabilis were obtained from a total of 38 patients with urinary tract infections in Al-Diwaniyah Teaching Hospital. All isolates were diagnosed with phenotypic, microscopic and biochemical tests. PCR technique was also used as a confirmatory test to investigate the $16 S$ rRNA gene (product size 239bp) in Proteus mirabilis , where the results showed the presence of the gene in all isolates .

On the other hand ,the detection of biofilm formation in Proteus mirabilis isolated from patients urinary tract infection was done using the tubes method .The results showed that $10(75 \%)$ isolates were capable of producing the biofilm, where the value of the optical density of the formed biofilm ranged from $0.064-0.411 \mathrm{~nm}$.

Then, the effect of diefferent temperatures $(25,3037,40){ }^{\circ} \mathrm{C}$ on the Biofilm Formation in Proteus mirabilis was studied, Where the most efficient bacteria were selected in the production of the biofilm and the test was carried out .The results showed that the bacteria were unable to form the biofilm at $25^{\circ} \mathrm{C}$ either at $3040^{\circ} \mathrm{C}$, the biofilm is very thin at $37^{\circ} \mathrm{C}$ and $40^{\circ} \mathrm{C}$, it becomes a thick biofilm.

The results of the current study showed that the temperature has a significant effect on the production of the biofilm and that the thickness of the biofilm increases with increasing temperature.
\end{abstract}

Key words: Proteus mirabilis 'Biofilm Formation, PCR, Virulence factors, Antibiotic resistence, Tubes method 


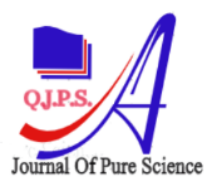

\section{Al-Qadisiyah Journal Of Pure Science (QJPS)}

Vol. 24, No. 4, pp. $44-50$, Year 2019

\section{Introduction}

Proteus mirabilis is one of the most important species of the genus Proteus, a negative bacilli to gram stain and belonging to the family of Enterobacteraceae. Proteus mirabilis causes many diseases, especially urinary tract infection, particularly in the upper part of it, and sometimes this type of infection leads to nephritis of the kidney (Swierzko et al.,2000) . P.mirabilis is the second pathogen, after Escherichia coli, to cause UTI and frequent infection in hospitalized patients and the users of urinary catheters for a long period of time (Sabbauba et al. 2003).

The pathogenesis of this bacteria is associated with its possession of many virulence factors which include Fimbria, Flagella, Urease, protease ,hemolysin production and lipopolysaccharide which is called endotoxin, Protease and Urease are inherent virulence factors produced by all strains of Proteus spp, which is an important diagnostic and differentiating characteristic of this genus in relation to some genera of enterobacteraceae (Brooke et al., 2007).

Proteus mirabilis produces protease to protect itself from the body's immune defenses (Dattelbaun et al., 2003) , Proteus also have the ability to form the phenomenon of swarming, this phenomenon results from the migration of a group of bacterial cells after differentiation, forming a thin layer of extended rings, the movement of the swarming is one of the important factors of virulence in Proteus bacteria to cause urinary tract infection, bacteria can invade different parts of the urinary tract through this movement by rapid whip which increases the pathogenicity of the Proteus bacteria and make them able to invade and colonize the kidneys (Liaw et al., 2001). Proteus mirabilis lives in a form of complex assemblies that are attached to the surface in an irreversible manner rather than in an organization of free cells and arranged in a staff of compact layers in the exterior cellular materials as they are difficult to remove and penetrate, forming what is called a bioflim that causes many damages (Hadjifrangiskou et al., 2012).

The formation of the biofilm is dangerous because its danger lies in its resistance to most antibiotics, due to the presence of several mechanisms that enable it to reduce or inhibit these antigens and also enhances the resistance of bacteria to the immune response (Ashraf et al., 2015).

The current study aimed at the following: Isolating and diagnosis Proteus mirabilis, detecting its ability to form the biofilm and studying the effect of different temperatures on the formation of the biofilm.

\section{Materials and method}

\subsection{Samples collection}

38 urine samples were collected from patients with urinary tract infection who were hospitalized and attending Al-Diwaniyah Teaching Hospital for the period from November 2018 to January 2019 , During collection of samples, it was careful to neglect the first drops of the urine and take the middle amount from it and store it in sterile collection tubes, then samples were transferred to Microbiological laboratory in the College of Science for culturing and diagnosis.

Samples were cultivated in on the MacConkey agar by Streaking method and incubated at $37^{\circ} \mathrm{C}$ for 18 24 hours (MacFaddin, 2004).

\subsection{Isolation and diagnosis of Proteus mirabilis}




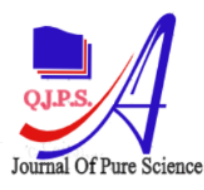

\section{Al-Qadisiyah Journal Of Pure Science (QJPS)}

Vol. 24, No. 4, pp. 44-50, Year 2019

The phenotypic characteristics of each of the bacterial colonies growing on different culture media were studied in terms of color, shape, texture, edges, growth or lack of growth on selective media, as the focus was on colonies that were distinguished by the phenomenon of swarming in the blood agar. Smears were also made directly from the culture media and stained with a Gram stain to study the microscopic properties of the isolated bacterial species that included the shape of the bacterial cell, the regularity of the bacterial cells together, and the nature of their interaction with the Gram stain . Biochemical tests were performed according to the method (MacFaddin, 2004).

\subsection{Detection of the Biofilm Formation}

Tube methods were used to detect of bacteria for formation of the biofilm according to (Hassan et al., 2011) as follows:

1- Inoculate the tubes containing glucose and (Brain heart infusion broth) with bacteria, then incubate at $25,30,37,40^{\circ} \mathrm{C}$ for 24 hours.

2- After the incubation period, the medium was disposed of and the tubes washed with buffered saline phosphate solution, then dried and stained with a crystal violet tincture for 3 minutes.

3- Then the excess dye was removed and the tubes washed with distilled water then the tubes were turned in order to dry, if it is observed that biofilms in the bottom and sides of the tube are in the form of a violet layer, as the optical density of the biofilm formed and measured by spectrophotometer at a wavelength of $640 \mathrm{~nm}$.

\subsection{Polymerase chain reaction (PCR)}

The polymerase chain reaction was examined to diagnose Proteus mirabilis, as the genomic DNA of Proteus mirabilis was extracted according to the manufacturer's instructions for Promega kit, USA, and the concentration and purity of the DNA samples were measured by the Nanodrop optical density meter spectrophotometer. The polymerase chain reaction mixture was prepared using the AccuPower ${ }^{\circledR}$ PCR PreMix kit prepared by (Bioneer, Korea) and according to the company instructions as in Table (1). The prefixes used (16S rRNA gene) were prepared by Bioneer, Korea ( $\mathrm{F}=$ GCGAGTCTGATGTTTGTCGC and $\mathrm{R}=$ TAAAGGTGGCGTCGGCATTA), and after completing the preparation of the polymerase chain reaction mixture the tubes were closed and carefully mixed with the vortex mixer for 5 seconds. The reaction was performed in a thermocycler by set up the following thermocycler conditions; initial denaturation temperature of $94{ }^{\circ} \mathrm{C}$ for $5 \mathrm{~min}$; followed by 30 cycles at denaturation $94{ }^{\circ} \mathrm{C}$ for 30 s, annealing $59^{\circ} \mathrm{C}$ for $30 \mathrm{~s}$, and extension $72{ }^{\circ} \mathrm{C}$ for $1 \mathrm{~min}$ and then final extension at $72{ }^{\circ} \mathrm{C}$ for $5 \mathrm{~min}$. The PCR products were examined by electrophoresis in a $1.5 \%$ agarose gel, and visualized under UV illumination.

Table (1): PCR master mix components and volumes

\begin{tabular}{|c|c|}
\hline Volume & \multicolumn{2}{|c|}{ PCR master mix } \\
\hline $5 \mu \mathrm{L}$ & DNA template \\
\hline $1.5 \mu \mathrm{L}$ & Forward P. \\
\hline $1.5 \mu \mathrm{L}$ & Reverse P. \\
\hline $12 \mu \mathrm{L}$ & \multicolumn{2}{|c|}{ Deionized D. W } \\
\hline $20 \mu \mathrm{L}$ & \multicolumn{2}{|c|}{ Total } \\
\hline
\end{tabular}

\section{Results and discussion}

\subsection{Isolation and diagnosis}




\section{Al-Qadisiyah Journal Of Pure Science (QJPS)}

Vol. 24, No. 4, pp. 44-50, Year 2019

15 isolates (39.4\%) of Proteus mirabilis were obtained from a total of 38 patients with urinary tract infections in Al-Diwaniyah Teaching Hospital. All isolates were diagnosed with phenotypic, microscopic and biochemical tests, Proteus mirabilis appeared as pale colonies on MacConkey agar as a result of its inability to ferment lactose sugar, and wavy or swarming movement appeared on the blood Agar, which is a preliminary diagnostic trait of this bacterium.

\section{Molecular identification}

PCR technique was also used as a confirmatory test to investigate the 16S rRNA gene (product size 239bp) in Proteus mirabilis, where the results showed the presence of the gene in all isolates as in Figure (1).

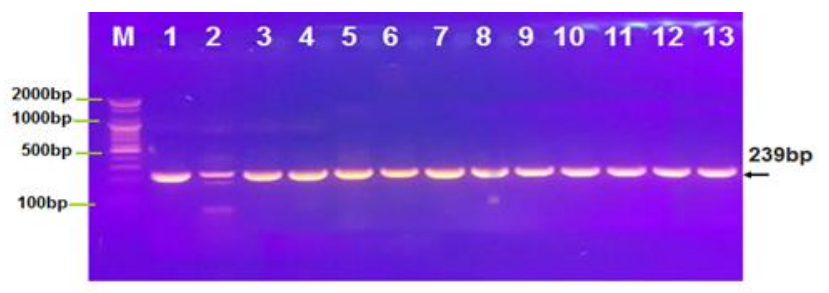

Figure (1) Electrophoresis gel migration $1.5 \%$ of the $16 \mathrm{~S}$ rRNA gene in Proteus mirabilis at $239 \mathrm{bp}$ product size

\subsection{Biofilm Formation}

The detection of biofilm formation by Proteus mirabilis that isolated from urinary tract infection was done using the tubes method, where the positive result as purple color on the bottom and inner walls of the tube by measuring the optical density of the crystal violet in the spectrophotometer at a wavelength of $640 \mathrm{~nm}$. The results shown in Figure (2) and Table (2) reaved that 10 isolates $(75 \%)$ out of 15 isolates are able to produce the biofilm, where the value of the optical density of the formed biofilm ranged from 0.064 $0.411 \mathrm{~nm}$.

On the other hand, the effect of different temperatures $(25,30,37,40){ }^{\circ} \mathrm{C}$ was studied on the formation of the biofilm in Proteus mirabilis, where the most efficient isolates in the production of the biofilm (depending on the thickness of the membrane in the tube) was selected and tested. The results shown in Figure (3) and Table (3) showed that there is a great variation in the production of the biofilm with the difference in temperature, as it was observed that bacterial isolation was $\mathbf{4} \quad \mathbf{3}$ 2 $25^{\circ} \mathrm{C}$ or $30^{\circ} \mathrm{C}$, so the biofilm is very thin. Whereas at a temperature of $37^{\circ} \mathrm{C}$ and $40^{\circ} \mathrm{C}$ it may be a thick biofilm, meaning that the thickness of the biofilm increases with increasing temperature and a certain extent.

Biofilm production is one of the virulence factors that Proteus mirabilis possesses, as it allows bacteria to stay longer at the site of infection (Hanna et al., 2003). Bacteria produce the biofilm in response to a many factors including nutrient deficiency and low pH (Sharma et al., 2014). Biofilm production gives bacterial isolates many traits, including the antibiotic resistance and resistance to phagocytosis. The biofilm is the main cause of persistent infection (Soto et al., 2007). 


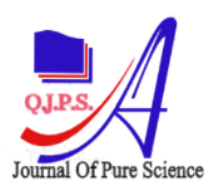

\section{Al-Qadisiyah Journal Of Pure Science (QJPS)}

Vol. 24, No. 4, pp. $44-50$, Year 2019

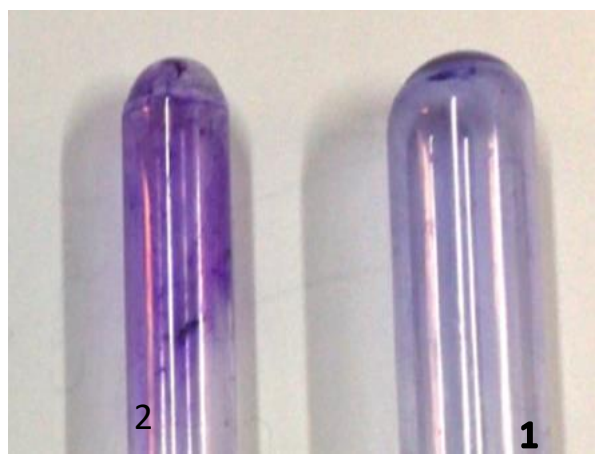

Figure 2: Biofilm production by Proteus mirabilis

\section{1. control}

2. Biofilm formation

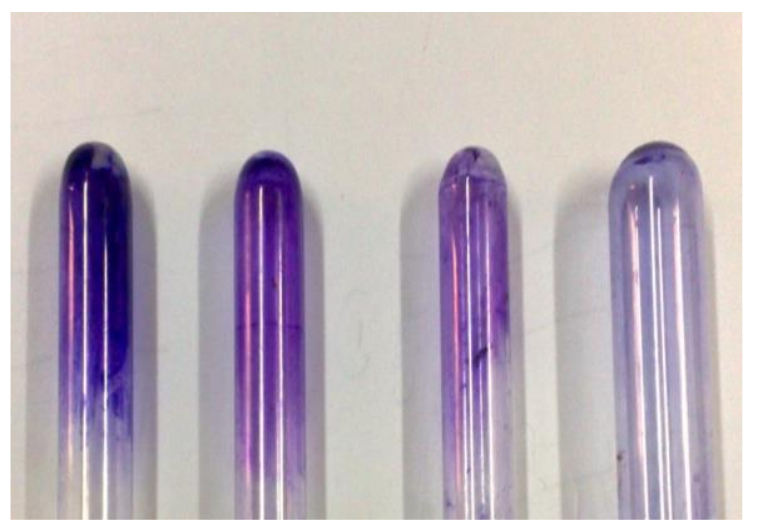

Figure( 3): The formation of the biofilm in Proteus mirabilis with the effect of different temperatures

1- The formation of the biofilm at $25^{\circ} \mathrm{C}$.

2- The formation of the biofilm at $30^{\circ} \mathrm{C}$

3- The formation of the biofilm at $37^{\circ} \mathrm{C}$

4- The formation of the biofilm at $40{ }^{\circ} \mathrm{C}$

Table (2) Biofilm Production by Proteus mirabilis

\section{No. of isolates $\quad$ Biofilm Production OD $_{640 \mathrm{~nm}}$}

\begin{tabular}{|c|c|}
\hline P 1 & $0.326+++v e$ \\
\hline P 2 & $0.400+++v e$ \\
\hline P 3 & $0.304+++v e$ \\
\hline P 4 & $0.404+++v e$ \\
\hline P 5 & $0.388+++v e$ \\
\hline P 6 & $0.411+++v e$ \\
\hline P 7 & $0.277++v e$ \\
\hline P 8 & $0.224++v e$ \\
\hline P 9 & $0.240++v e$ \\
\hline P 10 & $0.120+v e$ \\
\hline P 11 & $0.077-$ ve \\
\hline P12 & $0.098-$ ve \\
\hline P13 & $0.064-$ ve \\
\hline
\end{tabular}

Whereas :

$-\mathrm{V}=$ no biofilm formation

$+\mathrm{V}=$ thin biofilm formation

$++\mathrm{V}=$ moderate biofilm formation

$+++\mathrm{V}=$ thick biofilm formation

$\mathrm{P}=$ P.mirablis 


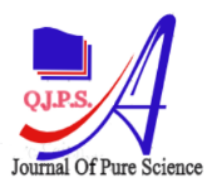

\section{Al-Qadisiyah Journal Of Pure Science (QJPS)}

Table (3) : Effect of diefferent temperatures on biofilm formation

\begin{tabular}{|c|c|c|c|c|}
\hline No. of & Contr & \multicolumn{3}{|c|}{ Biofilm formation $\left(\mathbf{O D}_{\mathbf{6 4 0 n m}}\right)$} \\
\cline { 3 - 5 } $\begin{array}{c}\text { isolate } \\
\text { S }\end{array}$ & $\begin{array}{c}\text { ol } \\
{ }^{\circ} \mathrm{C}\end{array}$ & $\mathbf{4 0}^{\circ} \mathrm{C}$ & $\mathbf{3 0}^{\circ} \mathrm{C}$ & $\mathbf{2 5}^{\circ} \mathrm{C}$ \\
\hline P 1 & 0.366 & 0.303 & 0.219 & 0.166 \\
& $(+++\mathrm{v}$ & $(+++\mathrm{v}$ & $(++\mathrm{ve})$ & $(+\mathrm{ve})$ \\
\hline P 2 & 0.400 & 0.344 & 0.265 & 0.199 \\
& $(+++\mathrm{v}$ & $(+++\mathrm{v}$ & $(++\mathrm{ve})$ & $(+\mathrm{ve})$ \\
\hline P 3 & $\mathrm{e})$ & $\mathrm{e})$ & & \\
\hline & 0.384 & 0.315 & 0.232 & 0.143 \\
& $(+++\mathrm{v}$ & $(+++\mathrm{v}$ & $(++\mathrm{ve})$ & $(+\mathrm{ve})$ \\
\hline P 4 & $\mathrm{e})$ & $\mathrm{e})$ & & \\
\hline & 0.404 & 0.337 & 0.267 & 0.194 \\
& $(+++\mathrm{v}$ & $(+++\mathrm{v}$ & $(+++\mathrm{ve})$ & $(+\mathrm{ve})$ \\
\hline P 5 & $\mathrm{e})$ & $\mathrm{e})$ & & \\
& 0.388 & 0.322 & $0.265(++\mathrm{v}$ & 0.166 \\
& $(+++\mathrm{v}$ & $(+++\mathrm{v}$ & $\mathrm{e})$ & $(+\mathrm{ve})$ \\
\hline P 6 & $\mathrm{e})$ & $\mathrm{e})$ & & \\
\hline & 0.411 & 0.335 & $0.261(++\mathrm{v}$ & $0.189(+\mathrm{v}$ \\
& $(+++\mathrm{v}$ & $(+++\mathrm{v}$ & $\mathrm{e})$ & $\mathrm{e})$ \\
& $\mathrm{e})$ & $\mathrm{e})$ & & \\
\hline
\end{tabular}

Whereas :

Control $=$ biofilm formation at 37

$+\mathrm{V}=$ thin biofilm formation (OD between 0.1 -

$0.199)$

$++\mathrm{V}=$ moderate biofilm formation (OD between

$0.2-0.299$ )

$+++\mathrm{V}=$ thick biofilm formation $(3 \mathrm{OD} \geq 0$. $)$

$\mathrm{P}=$ P.mirablis

\section{References}

Ashraf, F.; Iram, S.; Riaz, Gul-e-Zar.; Rasheed, F.andShaukat, M.(2015). Comparison between non-catheterized and catheter associated urinary tract infections caused by extended spectrum Blactamase producing Escherichia coli and Klebsiellapneumoniae. IJSR.4(4): 1223-1227.

Brooks, G.F. ; Butel, J.S. and Mores, S.A.(2007). Medical Microbiology . Jawetz and Menick and Adelberg's (eds) . 23rded . Appleton and Lange ,USA., :250-252.

Dattelbaum, J. D. ; Lockatell ,C. V.; Johnson, D. E. ; Harry ,L. and Mobley, T. (2003). UreR, the transcriptional activator of the Proteus mirabilis urease gene cluster is required for urease activity and virulence in experimental urinary tract infections. Infections and Immunity.71(2):1026-1030.

Hadjifrangiskou, M.; Gu, A. P. ; Pinkner, J. S.; Kostakioti , M.; Zhang, E. W. ; Greene, S. E. and Hultgrena , S. J. (2012). Transposon mutagenesis identifies uropathogenicEscherichia coli biofilm factors. J. Bact. 194(22) : 6195-6205.

Hanna, A., Berg, M., Stout, V. \&Razatos, A. (2003). Role of capsular colanic acid in adhesion of uropathogenic Escherichia coli. Applied Environmental Microbiology, 69 (8), pp: 4474-4481.

Hassan, A. Usman, J., Kaleem, F., Omair, M., Khalid, A., \&Iqbal, M. (2011). Evaluation 


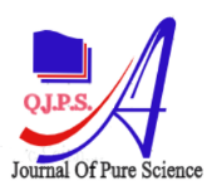

\section{Al-Qadisiyah Journal Of Pure Science (QJPS)}

Vol. 24, No. 4, pp. $44-50$, Year 2019

of different detection methods of biofilm formation in the clinical isolates. The Brazilian Journal of Infectious Diseases, 15(4), 305-311. Liaw,S.J., Lai, H.C.; Ho, S.W.; Luh, K.T.; Wang, W.B.(2003). Role of RsmA in the regulation of swarming motility and virulence factor expression in Proteus mirabilis. Journal of Medical Microbiology. 52: 19-28.

Macfaddin, J.F. (2004).Biochemical test for bacteria, $3^{\text {nd }}$ ed.the Williams andWilkins. London. identification of medical Microbiology $.8^{\text {th }}$ ed .The McGraw-Hill Companies.USA.

Sabubba, N. A. ; E. Mahenthiralingan and D. J. Stickler (2003). Molecular epidemiology of Proteus mirabilis infections of the catheterized urinary tract. Clin. Microbiol.41 (11) : $4961-4965$.

Sharma, G., Rao, S., Bansal, A., Dang, S., Gupta, S. \&Gabrani, R. (2014) • Pseudomonas aeruginosa biofilm : potential therapeutictargets .J. Biologicals . 42(1): 1-7 .

Soto, S. M., Smithson, A., Martinez, J. A., Horcajada, J. P., Mensa, J., \& Vila, J. (2007). Biofilm formation in uropathogenic Escherichia coli strains: relationship with prostatitis, urovirulenc factors and antimicrobial resistance. The Journal of urology, 177(1), 365-368.

Swierzko, A.S.; Kirikae, T.; Kirikae, F.; Hirata, M.; Cedzynsk, M.; Ziolkowski, A.;
Hirai, Y.; Kusumoto, S.; Yokochi, T.;and Nakano, M.(2000). Biological Activities of Lipopolysaccharides Of Proteus Species \& Their Interactions With Polymyxin-B and An 18-Kda Cationic Antimicrobial Protein (cap 18) Derived Peptide. J.Med.Microbiology. 49(2): 127-138. 